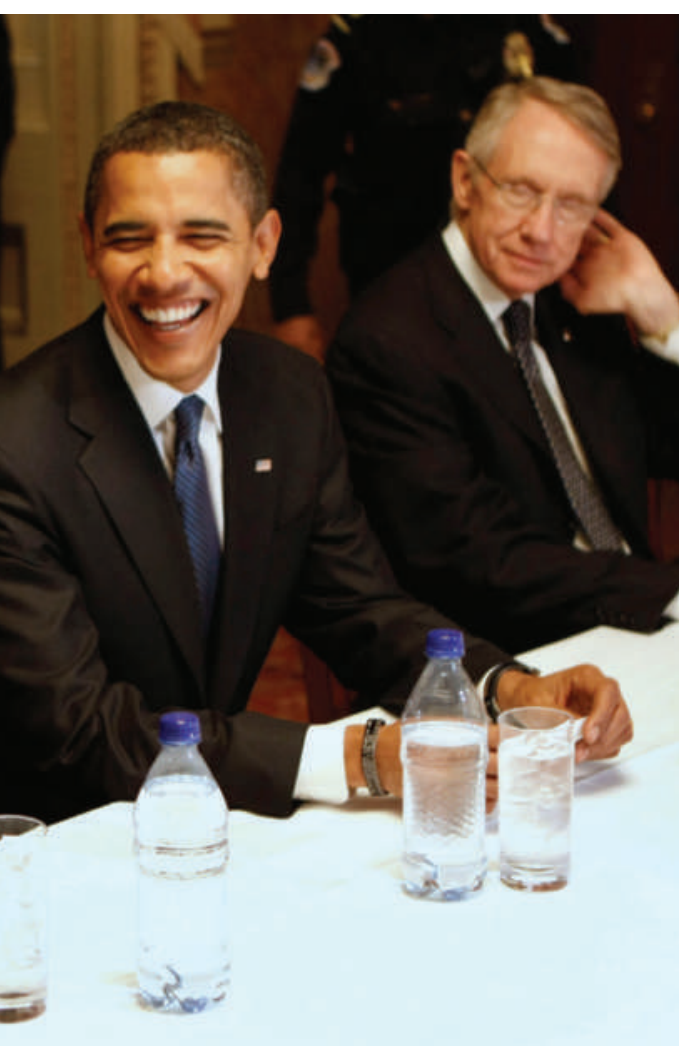

Barack Obama and Congressional Democrats brought scientists and economists to the table.

Obama has also called for modernization of the electricity grid, an initiative that could cost upwards of $\$ 165$ billion, according to the Electric Power Research Institute.

Democratic lawmakers are keen to include energy-efficiency initiatives, including weatherproofing assistance for homeowners, but questions remain about how to address renewable energy in the bill. Officials in the wind and solar energy industries say Obama's goal of doubling renewableenergy production was possible before the economic meltdown, but financing for new projects has since dried up, forcing some companies to lay off workers.

These industries are now pushing lawmakers to free up money by altering the structure of federal tax incentives that encourage the development of electricity from renewables - a move that could cost taxpayers an additional $\$ 1$ billion over the next two years. Rhone Resch, who heads the Solar Energy Industries Association in Washington DC, says the industry is ready to go to work once it can get the financing. "The policies and the programmes that worked in the past economy will not work in today's dire economic environment," he says. Jeff Tollefson

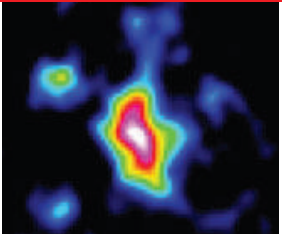

ASTRONOMY

Did black holes form before galaxies?

www.nature.com/news

\title{
Steven Chu prepares for power
}

On 13 January, the US Senate Committee on Energy and Natural Resources was scheduled to hold a hearing on presidentelect Barack Obama's nomination of Steven Chu for head of the Department of Energy (DoE). If confirmed as expected, Chu may well set sparks flying at the staid agency. Over the past four years, Chu has realigned the DoE's Lawrence Berkeley National Laboratory (LBNL) in California into a pioneer for alternative-energy research.

Using an ice-hockey analogy, Eddy Rubin, director both of the Joint Genome Institute in Walnut Creek, California, and of the genomics division at the LBNL, says: "You can't stay where the puck is - you have to skate where the puck is going to be. [Chu] had a compelling vision to put the lab where it needs to be."

Like many hockey greats, Chu isn't shy about asserting his position. "You say something stupid, he smacks you immediately," says one lab source who asked to remain anonymous. "I've seen him really embarrass people, to a fault."

Chu, 60, is not granting interviews until after his confirmation. But a week before Christmas, about 15 LBNL division heads and managers heard him explain how he visited Obama in Chicago around Thanksgiving, spending roughly 40 minutes alone with him. Obama was extremely knowledgeable about energy issues, Chu told the group, and their ideas for research on alternative sources were in sync.

According to the division directors, Chu said he would take the job if he could select the approximately 15 political appointees who would direct key DoE components. In the early days of the Bush administration, vice-president Dick Cheney was behind most of those appointments. Instead, "Chu will get to select the smartest people he knows", says Rubin.

Chu is deeply interested in biology, having branched far beyond the lasercooling work that won him his Nobel prize in 1997. And he is always delving into new fields, says geochemist Don DePaolo, a 20-year LBNL veteran appointed by Chu in 2007 to direct the Earth-sciences division. "In only four years at the LBNL, he learned so much about everything it is intimidating to talk to him," says DePaolo. "You can't tell him a story to patch over an issue; he zeroes in if it doesn't sound right."

But this focus has led to complaints of micromanagement. Colleagues say he "always has to be the smartest guy in the room", even privately voicing desires for a second Nobel in a biology-related field.

"He is an unabashed self-promoter," says Tad Patzek, a former researcher at the University of California, Berkeley, who clashed with Chu on bioenergy projects that Patzek considered to be 'nonsense' before moving last summer to the University of Texas at Austin. "But in fairness, he has been a very effective $L B N L$ director, enlarging the scope of energy research."

Chu has mellowed in recent years, says Stephen Quake, a biophysicist at Stanford University in California, who studied under Chu. "Everything is about the science," Quake says. "I could go into his office and tell him why I thought something he requested wouldn't work; he listened."

Three years ago at the LBNL, Chu championed an initiative called Helios to develop new research frontiers in solar power. Its flagship facilities, to be built in partnership with the University of California, Berkeley, have been delayed by environmental lawsuits and community

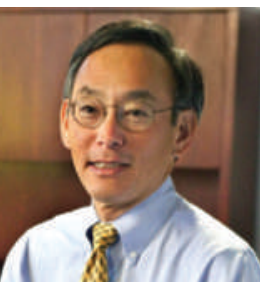

Steven Chu realigned the Lawrence Berkeley National Laboratory. objections, but are now being re-reviewed.

In 2007, Chu was also instrumental in helping the university win US\$500 million for bioenergy research from $\mathrm{BP}$, one of the world's largest energy companies - a project that triggered controversy about the role of corporate financing in academic research (see Nature 445, 688-689; 2007). That research programme has begun on the Berkeley campus, but its building is delayed along with Helios. Last year, the LBNL did successfully open its \$134-million Joint BioEnergy Institute in a gleaming facility at an industrial park in nearby Emeryville.

Chu's experience in setting up these initiatives may serve him well in Washington DC, which is full of people who think they are the smartest in the room. "He is going to take the DoE where it needs to go with new technologies," says Rubin. "He's a driver who doesn't take vacations." Rex Dalton

For coverage of Steven Chu's confirmation hearing, see http://tinyurl.com/8dgwle. 